\title{
Archaeo-Aurora and Geomagnetic Secular Variation in Historic Time
}

\author{
Mitsuo Keimatsu \\ College of Liberal Arts, Kanazawa University, Kanazawa \\ Naoshi FukUshima and Takesi NAGATA \\ Geophysics Research Laboratory, University of Tokyo, Tokyo
}

(Received January 5, 1968)

\begin{abstract}
In order to trace the secular variation of the geomagnetic field in historic time, the documents of ancient aurorae can be utilized. In China, Korea and Japan, there are a number of valuable records, which can be reasonably supposed to describe the events of auroral appearance. After a comparison of these descriptions with those in Europe, the archaeo-secular variation in the geomagnetic field can be inferred. A preliminary examination of the auroral appearance on the same day in the Occident and Orient suggests that the geomagnetic dipole axis might have been inclined towards China around 11-12th centuries AD.
\end{abstract}

\section{Introduction}

The secular variation of the geomagnetic field is an important problem in earth and planetary sciences. The principal source of the data for discussion has been the fossilized magnetization of natural rocks or baked clays in geologic and historic times. Here we present a completely different approach, which may also contribute to the study of archaeosecular variation in the geomagnetic field, i.e., through the comparison of the historical aurorae observed at different places, because the location of auroral appearance is subjected to the geomagnetic field distribution over the earth. For this study, we have examined the historical descriptions of aurorae in ancient documents. The study of archaeo-auroae and its application to geomagnetism is possible as a result of close collaboration between research wokers in the fields of history/literature and geophysics. Though the study is still in progress, a preliminary report is presented here to show the usefulness of this work.

\section{Ancient auroral records in China}

In China unusual events on the earth and in the sky have been described by specialists in the royal astronomical observatories established by the central government, and the documents have been carefully preserved for thousands of years. Therefore, we can trace ancient events in China as to their exact dates and details, though descriptions are sometimes given in poetic or exaggerated expressions. Among descriptions of natural phenomena in the sky with the following words, some cases are supposed to describe aurorae.

天 狗 (heaven-liondog): like huge running stars with tails, like a flame going up to heaven. 
帰 邪: like stars but not stars, like clouds but not clouds.

格沢星: like a flame, yellowish white, rising from the ground up to the sky, the bottom is flat and top is sharp.

虫尤旗: like comets but with a snaky tail, and like flags.

枉矢: arrows like large comets, snaky and blue-black, seeming to have hairs.

長 庚: a piece of cloth in the sky.

衆星如雨: many stars fall like rain.

赤気: reddish form or veil.

白 気: whitish form or veil.

The above words are often followed by the comment that unusual phenomena in the heaven may predict a new war, an agricultural disaster, or some other unhappy event.

\section{Comparison of Occidental and Oriental aurorae}

Table I gives a comparison of the number of descriptions of aurorae or auroral-like phenomena in each century, from $7 \mathrm{BC}$ to $10 \mathrm{AD}$, in the Occident and the Orient. Oriental records were taken mainly from Chinese documents, and partly from the Korean and Japanese literatures, and events were classified into four degrees of reliability according to the contents of the descriptions (Keimatsu, 1965). The Occidental records were taken from lists compiled by Fritz (1873) and Link (1962). In Table II, some examples of the auroral descriptions in the Occident and the Orient are compared with each other.

Table I. Comparison of Oriental and Occidental Aurorae during BC 7th...AD 10th Century.

\begin{tabular}{|c|c|c|c|c|c|c|c|c|c|}
\hline \multirow{2}{*}{ Century } & \multirow{2}{*}{$\begin{array}{l}\text { Number of description } \\
\text { of Oriental aurorae }\end{array}$} & \multicolumn{4}{|c|}{ Reliability* } & \multirow{2}{*}{$\begin{array}{l}\text { Number of description } \\
\text { of Occidental aurorae }\end{array}$} & \multirow{2}{*}{\multicolumn{3}{|c|}{$\begin{array}{l}\text { Coincidence of Occiden- } \\
\text { tal and Oriental aurorae } \\
\text { by year month day }\end{array}$}} \\
\hline & & 1 & 2 & 3 & 4 & & & & \\
\hline $\mathrm{BC} 7$ & 1 & 0 & 0 & 1 & 0 & 1 & - & - & - \\
\hline BC 6 & 0 & & & & & 3 & - & - & - \\
\hline BC 5 & 1 & 0 & 0 & 1 & 0 & 4 & - & - & - \\
\hline $\mathrm{BC} 4$ & 0 & & & & & 2 & - & - & - \\
\hline BC 3 & 1 & 0 & 0 & 1 & 0 & 6 & - & - & - \\
\hline $\mathrm{BC} 2$ & 8 & 0 & 0 & 7 & 1 & 12 & 3 & - & - \\
\hline $\mathrm{BC} 1$ & 8 & 2 & 4 & 2 & 0 & 9 & 1 & - & - \\
\hline $\mathrm{AD} 1$ & 7 & 0 & 0 & 5 & 2 & 5 & - & - & - \\
\hline $\mathrm{AD} 2$ & 15 & 1 & 4 & 4 & 6 & 1 & - & - & - \\
\hline $\mathrm{AD} 3$ & 11 & 0 & 0 & 10 & 1 & 0 & - & - & - \\
\hline $\mathrm{AD} 4$ & 24 & 1 & 11 & 9 & 3 & 2 & 1 & - & - \\
\hline AD 5 & 8 & 2 & 4 & 1 & 1 & 5 & - & - & - \\
\hline $\mathrm{AD} 6$ & 16 & 2 & 10 & 3 & 1 & 17 & 6 & 1 & - \\
\hline $\mathrm{AD} 7$ & 9 & 0 & 2 & 7 & 0 & 3 & 1 & - & - \\
\hline $\mathrm{AD} 8$ & 31 & 4 & 7 & 17 & 3 & 10 & 4 & 1 & - \\
\hline $\mathrm{AD} 9$ & 43 & 1 & 13 & 25 & 4 & 21 & 8 & 2 & - \\
\hline $\mathrm{AD} 10$ & 54 & 6 & 18 & 25 & 5 & 22 & 10 & 3 & 2 \\
\hline Total: & 237 & 19 & 73 & 118 & 27 & 123 & 34 & 7 & 2 \\
\hline
\end{tabular}

* Reliability: 1 certain, 2 very probable, 3 probable, 4 doubtful. 


\begin{tabular}{l}
\hline $\mathrm{BC} 15,3.23$ \\
at Sian (Siking) $\left(34^{\circ} 16^{\prime} \mathrm{N}, 108^{\circ} 54^{\prime} \mathrm{E}\right)$ \\
夜東方有赤色, 大三四囲, 長二三丈, 索索如 \\
樹, 南方有大四五囲, 下行十余丈, 皆不至地滅 \\
At night a reddish form 20 feet $^{1}$ round and \\
20-30 feet long shook like a tree in the \\
eastern sky. On its southern side, a similar \\
form about 25 feet in circumference and \\
more than 100 feet long also hung in the \\
sky. Both disappeared before reaching the \\
earth.
\end{tabular}

AD 567, 5.31.

At Anyang $\left(36^{\circ} 21^{\prime} \mathrm{N}, 114^{\circ} 35^{\prime} \mathrm{E}\right)$

甲夜西北有赤気竟天, 夜中始隇

Around $20 \mathrm{~h}$ reddish rays first appeared in the northwestern sky, and then spread over the heavens, disappearing after midnight.

AD 786, 11.26-12.24

at Sian (Siking) $\left(34^{\circ} 16^{\prime} \mathrm{N}, 108^{\circ} 54^{\prime} \mathrm{E}\right)$

日没有赤気五, 出干黒雲中亘天

After sunset five reddish rays came out of black clouds and spread over the sky.
BC 15 (16?). (after Link)

Jul. Obsequens (Supple. L.)

C. Furnio C. Silano Coss. fax coelestis a meridiano ad septentrionem extenta lucem diurnae similem nocte fecit...
AD 567. (after Fritz)

Mittel-Europa : Feuerige Lanzen am Himmel (Frob. nach Lyeosthenes).
AD 786, 12.19. (after Link)

Dans les Annales Francorum (Du Chesne 2, 23) : Et six dies ante Natale Domint tonitrua et fulgura per totam Franciam...et arcus coeli in nubibus apparuit per noctem. $\mathrm{Au}$ même phénomène se rapporte sans doute le passage suivant dans le Chronicon Moissiacense (Bouquet 5.72): Eo anno mense Decembri apparuerunt acies terribiles in coelo quales antea nostris temporibus nunquam apparuerunt.

AD 786, Dec? (after Fritz)

Feuerige Lanzen am Himmel.
AD 937, 2.14.

at Loyang $\left(34^{\circ} 46^{\prime} \mathrm{N}, 112^{\circ} 26^{\prime} \mathrm{E}\right)$

初北方有赤気, 西戌亥地東北至丑地, 南北闊 三丈. 状如火光. 赤気内見紫微宮及北斗諸星. 至三点後内白気数条次行至西. 夜半子時方散 Fist a reddish veil 30 feet long appeared in the north, moved NNW to NWW, and back to NNE, like a flame. The tzŭ-weiyüan and big-dipper stars could be seen through the reddish veil. After three hours several whitish rays moved westwards one after another, and disappeared around midnight.

Note: The tzŭ-wei-yüan is an old Chinese name of a constellation around the celestial north pole. It consists of more than 170 stars including those in Ursa Major, Ursa Minor, Draco, Cassiopeia, Cepheus and others.

AD 1138, 10.6. ${ }^{2}$

at Hangchow $\left(30^{\circ} 17^{\prime} \mathrm{N}, 120^{\circ} 10^{\prime} \mathrm{E}\right)$

夜赤気有如火出紫微宮.

At night a reddish veil like a flame appeared in the txŭ-wei-yüan.

正北方有赤気如火影.

Around the true north a flaming veil appeared in the sky.
AD 937, 2.14. (after Link)

Ordericus Vitalis dans Eccl. Historia (Bouquet

9,17) écrit: Secundo post haec anno XVI Kal. Martii circa gallorum ca ntum usque ad illucente die sanguineae acies per totam coeli faciem apparuerunt. Sequenti autem mense VIIII Kal. Hungri adhuc pagani Franciam etc....

Une relation analogue se trouve dans Hugo Flor. (Bouquet 8,322 ) et dans le Chronicon Turonensis (Bouquet 9,52), mais dans les Annales de S. Columbae Sen. (Pertz 1,105) on lit "6 Kal. Marc. circa etc."

Pour Lycosthenes le phénomène ainsi que 1 'invasion ont eu lieu en 930 . Frittz en a crée 1'aurore 930-II-12 qui est fausse.

AD 937, 2.14. (after Fritz)? Vom Hahnenschrei bis zum Tagesanbruch blutige Lanzen an allen Theilen des Himmels (Quet., Chasles nach verschiedenen Chroniken).

AD 1138, 10.6. (after Fritz)

Böhmen: Rothe Gestalten an der Mitternachtseite des Himmels.

AD 1138, 10.6. (after Seydl, originally by Strnad) Towards evening living red forms emerged in the North. The same occurred the following night and on the 7 th of October they emerged at dawn in the reddening morning sky.

1. Although the text is translated here word for word from the original description, the breadth and length of the light in the sky should not be taken quantitatively.

2. The dates in Table II are all given according to the Julian calendar. This record was referred to by Kawai and Hirooka (1967) as the aurora on Oct. 13, 1138 according to the Gregorian calendar. 


\section{Latitude difference of the southern boundary of aurorae simultaneously observed in Europe and Asia}

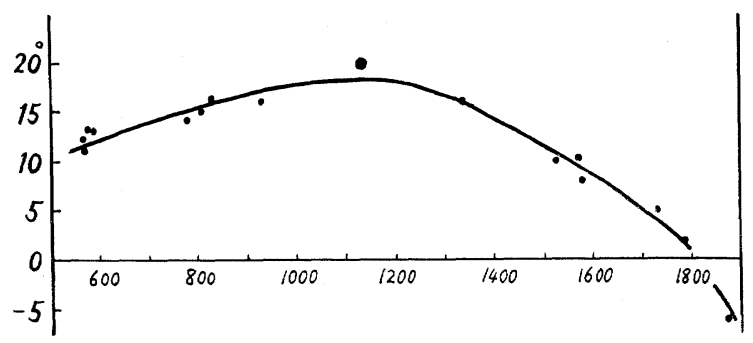

Fig. 1 Latitude difference of the southern boundary of aurorae borealis seen on the same days in Europe and China. The ordinate is : (geographic latitude of the auroral southern boundary in Europe)-(that in China). Abscissa is years AD.

From a comparison of simultaneous aurorae, we have estimated the latitude difference in the southern boundary of aurorae borealis seen in Europe and China (or sometimes Korea and Japan). This is plotted against year in Fig. 1. In this diagram the point for the event of 6 October, 1138, has the largest reliability compared with other points, because the southern boundaries of the auroral appearance on that day in Europe and China are most definitely known. Such an example is really a rare case. In order to obtain as many points as possible for Fig. 1, the following conventional method was adopted. For events recorded in early centuries, some aurorae in the same year are assumed to be of the same date, even when there is no definite evidence for this assumption. For aurorae in the later centuries, only those which appeared on exactly the same day were used. The estimated southern boundaries of aurorae may have an error of several degrees in latitude.

\section{Archaeo-variation of the geomagnetic axis}

Fig. 2 shows the present relation among the geographic coordinates, $40^{\circ}$ latitude line in centred-dipole geomagnetic coordinates, $40^{\circ}$ latitude line in the corrected geomagnetic latitude (proposed by Hakura, 1965), and the auroral isochasm of 0.1 in yearly average (according to Fritz, 1873). In the geomagnetic field distribution at the present time, the geomagnetic latitude in China is definitely lower than that of Central Europe, so that the appearance of aurorae is much less frequent in China than in Central Europe at present. However, the appearance of an aurora on the same day, e.g., on 6 October, 1138, in Bohemia (geographic latitude about $50^{\circ}$ ), and Hangchow in China (geogr. lat. $30^{\circ}$ ) suggests that the geomagnetic field distribution at that time might be quite different from that of the present time, i.e., the geomagnetic dipole axis might have been inclined towards the Asian side of the earth. This conclusion is obtained under some idealized assumptions, e.g., (1) the auroral appearance depends on the geomagnetic latitude of the observing location; (2) the geomagnetic field distribution has been mainly of a centred dipole type; (3) the size of the 


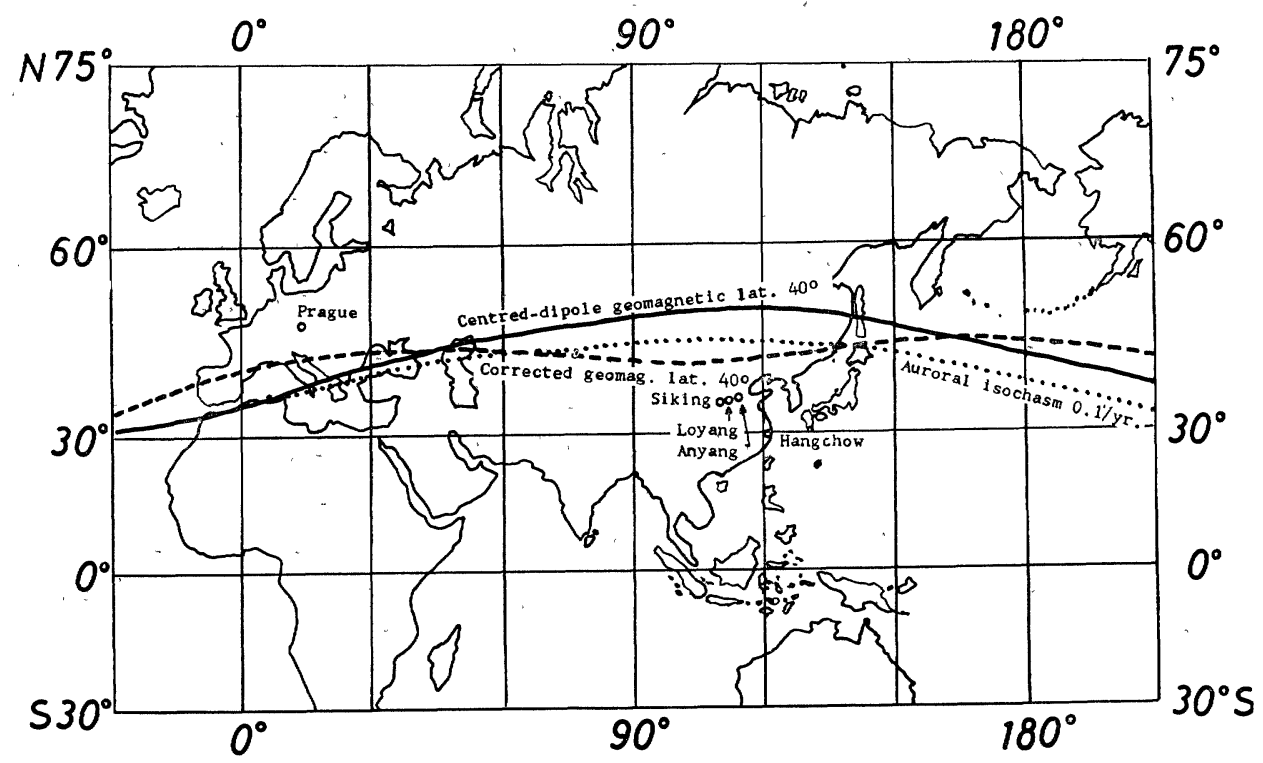

Fig. 2 Relation among geographic latitude, geomagnetic latitude of $40^{\circ}$ in centred-dipole coordinates, and in corrected geomagnetic coordinates, and Fritz' auroral isochasm of $0.1 /$ year.

auroral zone was almost the same at the times when the aurora was observed in Europe and in Asia.

Kawai et al. (1965) have shown that the axis of the earth's main dipole field might have rotated counter-clockwise in archaeolgoic time, and the axis might have been inclined towards Asia in the 10th-12th centuries, as illustrated in Fig. 3. They arrived at this conclusion after examining the archaeo-secular variation in the virtual geomagnetic pole positions (assuming a dipole approximation of the geomagnetic field), based on the remanent magnetization of rock and clay samples measured by research workers in England, France, Iceland, U.S.A., U.S.S.R.

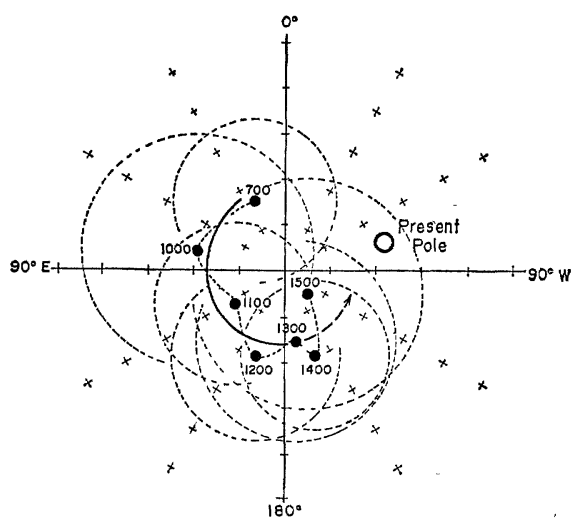

Fig. 3 Mean virtual pole position at 700 , $1000,1100,1200,1300,1400$ and 1500 AD. Broken circles indicate the region of $95 \%$ confidence. (after Kawai et al.)

and Japan. The geomagnetic dipole axis appears to have been inclined towards China around the 12th century. The curve in Fig. 1 obtained from a comparison of Occidental and Oriental aurorae seems to be in accordance with the result obtained by Kawai et al. (1965), through our preliminary result is still of insufficient accuracy to test the wobbling motion of the geomagnetic field in historic time as suggested by Kawai and Hirooka (1967). 


\section{Concluding remarks}

In order to trace the archaeo-secular variation in the geomagnetic field with the aid of historical records of ancient aurorae, it is desirable to examine descriptions in various regions of the world, if they exist and are available. However, even a simple comparison of aurorae observed in Central Europe and the Far East seems to show some validity for work of this kind. The present preliminary result suggests that the geomagnetic dipole axis might have inclined towards China around the 11-12 centuries AD. A more accurate study of the geomagnetic secular variation will be possible for the last several hundred years, with the aid of a considerable amount of detailed auroral descriptions taken at various places, such as those by Seydl (1954), Réthly and Berkes (1963), Lovering (1868), Matsushita (1956), and many original descriptions referred to in their papers. The writers hope that the future extension of this work can make an appreciable contribution to the study of archaeomagnetism. One of the authors (M.K.) is planning to publish a comprehensive list of historical aurorae in the Orient in the near future.

\section{Acknowledgement}

The writers are very grateful to Dr. M. Siebert, who kindly supplied us with a microfilm copy of the books by Fritz, and also to Drs. F. Link, O. Seydl and G. Sprague for their kind supply of useful material. We are indebted to Prof. N. Kawai for his discussion and encouragement.

\section{References}

Fritz, H., Verzeichniss beobachteter Polarlichter, Wien, 1873.

Hakura, Y., Tables and maps of geomagnetic coordinates corrected by the higher order spherical harmonic terms, Rep. Ionos. Space Res. Japan, 19, 121-157 (1965).

Kawai, N., and K. Hirooka, Wobbling motion of the geomagnetic dipole field in historic time during these 2000 years, $J$. Geomag. Geoelectr., 19, 217-227 (1967).

Kawai, N., K. Hirooka and S. Sasajima, Counterclockwise rotation of the geomagnetic dipole axis revealed in the world-wide archaeo-secular variations, Proc. Japan Acad., 41, 398-403 (1965).

Keimatsu, M., Documentary catalogue of northern lights observed in China, Korea and Japan from 7BC to 10AD (Preprint, College of Liberal Arts, Kanazawa University, 1965).

Link, F., Observations et Catalogue des Aurores Boréales Apparues en Occident de -626 à 1600. Travaux de l'Inst. Géophys. Acad. Sci., No. 173, Geofysikalni Sbornik, 297-387 (1962).

Lovering, J., On the periodicity of the aurora borealis, Memoirs Amer. Acad., New Series, 10, 1-40 (1868).

Matsushita, S., Ancient aurorae seen in Japan, J. Geophys. Res., 61, 297-302 (1956).

Réthly, A. und Z. Berkes, Nordlichtbeobachtungen in Ungarn (1523-1960), Akadémiai Kiado, Verlag der Ungarischen Akademie der Wissenschaften, Budapest, 1963.

Seydl, O., A list of 402 northern lights observed in Bohemia, Moravia and Slovakia from 1013 till 1951. Travaux de l'Inst. Géophys. Acad. Sci., No. 17, Geofysikalni Sbornik, 159-194 (1954). 